\title{
THE REPRESENTATION OF LOCAL CULTURE IN INDONESIAN EFL TEXTBOOKS: RATIONALES AND IMPLICATIONS
}

\author{
Yogi Saputra Mahmud \\ Faculty of Education, Monash University, Australia \\ E-mail: yogisaputramahmud@gmail.com; ymah0001@ student.monash.edu
}

\begin{abstract}
APA Citation: Mahmud, Y. S. (2019). The respresentation of local culture in Indonesian EFL texbooks: Rationales and implications. Indonesian EFL Journal, 5(2), 61-72. doi: 10.25134/ieflj.v5i2.1727.
\end{abstract}

\begin{abstract}
This article discusses the representation of local culture in EFL Junior High School textbooks in Indonesia. The two primary objectives of this paper are: 1) to reveal the primary reasons of incorporating local culture in EFL textbooks, and 2) to suggest further implications in responding to the incorporation of local culture in EFL textbooks. The discussion begins with the current EFL context in Indonesia with the emphasis on the considerable changes of the curriculum implementation in the Indonesian context, in which it attempts to reveal the representation of local culture implied within the 2013 curriculum. As its main arguments, this article argues that there are two predominant reasons for representing local culture in the EFL Junior High School textbooks in Indonesia which include promoting the sense of familiarity to Junior High School students in learning English as well as strengthening the aspects of national culture and identity portrayed in the textbooks. Furthermore, this article also discusses the future implications in responding to the representation of local culture in EFL Junior High School textbooks in Indonesia, including the needs to enhance the role of teachers as well as the importance of incorporating more diverse cultural representation in the textbooks.

Keywords: cultural representation; EFL; Indonesia; local culture; textbook.
\end{abstract}

\section{INTRODUCTION}

It has been widely acknowledged that globalization has impacted on revolutionary changes in terms of English usage around the world. Consequently, the English use in the global context has been categorised through the use of terms inner, outer, and expanding circles (Kachru, 1985, as cited in Fiedler, 2011). In this case, Indonesia is classified as one of the countries in the socalled expanding circle (Kachru, Kachru, \& Sridhar, 2008). Although English is not formally utilized within the society of the countries regarded as the expanding circle, this language is taught due to its importance as communication means with people with different cultural and national identities (Fiedler, 2011; Sharma, 2008, as cited in, Jayanti \& Norahmi, 2014). As a consequence, English gains popularity and even becomes one of the first foreign languages to be taught in Indonesia (Sukyadi, 2015; Yusny, 2013). In addition, this language is formally taught since the level of Junior High School.

In relation to the English language learning, many researchers have also emphasized on the inseparability between the notion of language and culture (Choudhury, 2013; Hall, 2013; Hermawan \& Noerkhasanah, 2012; Kramsch, 1998; Purba, 2011; Sorongan, Susanti, \& Syahri, 2014). As a result, this topic becomes an excellent source for researchers to investigate various topics, including what culture is represented and how the notion of culture is adopted, represented, and disseminated in the learning materials used in the classroom context (Hermawan \& Noerkhasanah, 2012). This research trend also emerges significantly in the Indonesian context.

In Indonesian EFL context, the contention of which culture is represented in the learning materials has been widely debated by numerous Indonesian scholars in various levels of schooling (see Erlina, et al., 2018; 
Hermawan \& Noerkhasanah, 2012; Munandar \& Ulwiyah, 2012; Prastiwi, 2013; Santosa, 2015; Sorongan, Susanti, \& Syahri, 2014). However, these studies primarily focus on analyzing the classification of which culture is portrayed in the textbooks, such as the so-called local culture, target culture, and international culture (see Cortazzi \& Jin, 1999), with fewer emphases on discussing the justification of why the cultural components are represented that way as well as the implications for the teachers and policymakers. Therefore, this paper attempts to extend the focus of discussion as well as enrich the body of literature in exploring different aspects of cultural representation in Indonesian EFL textbooks.

This investigation is primarily driven by the previous research findings which discover the integration of students' cultural values in language learning materials for Junior High School students in Indonesia. Furthermore, it is also stimulated by several concepts, including the English teaching phenomena in Junior High School, the inseparability between language and culture, the justification on why culture should be integrated on that schooling level, as well as some problems that might emerge in the learning context.

Ultimately, this paper is constructed to navigate the discussion through two research objectives: 1) to discover the reasons for incorporating students' local culture in the EFL learning materials for Junior High School and 2) to discuss some future implications in responding to the representation of local culture in the EFL material.

\section{EFL context in Indonesia}

The EFL curriculum in Indonesia regards English as a compulsory subject in Junior and Senior High School which eventually also be included in the National Examination (Jayanti \& Norahmi, 2014). Although some students might start learning English prior to Junior High School, this subject is classified either as an optional subject or as a localcontent subject in the public primary schools
(Hawanti, 2014). Consequently, depending on the available resources in the schools, English might or might not be taught in primary schools. Therefore, it can be stated that the students in Indonesia officially start acquiring English lesson intensively at Junior High School level.

Since many Indonesian students begin learning English in Junior High School, it is likely for the students to face unfamiliarity as they embrace a new language with different linguistic and cultural norms. Furthermore, as a so-called 'foreign language', this language is not used in daily contexts within Indonesian society. In other words, language can be primarily encountered in the classroom context. Graves (2008) utilizes the notion of 'target-language removed' context to portray the English usage that is mainly discovered in the classroom, rather than in the levels of educational institution, community, state, as well as the nation. Furthermore, the English curriculum in the 'target-language removed' context is primarily framed by provincial and national policies in education (Graves, 2008). This statement is also in line with the Indonesian EFL context in which the country has faced some different curriculum changes in the last decade.

As stated earlier, Indonesia has experienced considerable changes in terms of curriculum implementation. According to Prihantoro (2015), the curriculum changes in Indonesia can be classified into six significant periods, including (1) the 1975 Curriculum; (2) the 1986 Curriculum; (3) the 1994 Curriculum; (4) the Competency-Based Curriculum (2004); (5) the School-Based Curriculum (2007); and (6) the CharacterBased Curriculum (2013). As the latest curriculum policy in Indonesia, the 2013 curriculum was formally introduced in 2013, but it has just been implemented nationally in 2016 (Puspitasari, 2016). In this curriculum, it has been mandated clearly that the EFL context for Junior High School should include the cultural values within the learning context, including the learning materials. 
Before delving into the place of students' cultural identity in the 2013 curriculum, the focus of national education in Indonesia will be examined first which enacts as the foundation of conducting teaching and learning activities in Indonesia. According to the Law on the National Education System (No. 20/2003), the general principle of teaching and learning in Indonesia refers to the education that is "...based on Pancasila and the 1945 Constitution, and is rooted in the religious values, national cultures of Indonesia, and one that is responsive to the needs of the ever-changing era." This statement implies that there is a need to integrate the aspects of students' cultural identity in the curriculum context through the portrayal of Pancasila as the five foundational principles of the Indonesian state. Since this law also determines the basis of the curriculum establishment, the 2013 curriculum also mentions several concepts regarding cultural identity integration in the EFL context which will be examined further below.

In the 2013 curriculum, there are several documents which mention the emphasis on cultural identity integration regarding English language teaching in the classroom. The Content Standard of the 2013 Curriculum clarifies that the purpose of EFL in the Junior High School level is to enable students to communicate interpersonally, transactionally, and functionally about themselves, family and others, as well as concrete and imaginary objects surrounding the students' daily contexts and activities, including at home, school and the society (see Ministry of Education and Culture [MoEC], 2016). From this statement, it can be implied that there is an emphasis on the use of the students' cultural experiences as a great resource for English language learning. This statement is also strengthened by the mandated suggestion in the syllabus for Junior High School students in which the teachers are encouraged to adapt the learning materials based on the cultural and geographical characteristics of the students (see MoEC, 2016c). When the students

\section{https://journal.uniku.ac.id/index.php/IEFLJ/index}

engage with descriptive texts, for instance, they are encouraged to learn how to describe and promote traditional elements (e.g. tourist attractions, traditional food, crafts, and so on) surrounding their community (see MoEC, 2016c). Consequently, this will also impact on the integration of students' cultural identity in the learning materials published officially by the government.

The educational policies implemented in a particular region will mostly impact on the learning materials production, including textbooks (Widodo, 2018). Furthermore, the textbooks also enact not only as a learning document, but also as "a social and cultural artefact" that features several concepts, including cultural values, social norms, national ideologies, and others (Widodo, 2018, p.132). In Indonesian context, textbooks should also be in line with the values of Pancasila, the 1945 Convention as well as the positive norms within the society (see MoEC, 2016b). Therefore, it can be implied that textbooks, not to mention the textbook for the English subject, can guide learners to engage with the cultural and ideological values as well as to enlighten them on the shared ways of perceiving and valuing as a member of society.

Regarding the types of English textbooks utilized in public Junior High School in Indonesia, there are two types of textbooks used in the classroom. First, the government textbooks endorsed by the MoEC that can be accessed at The Center of Curriculum and Materials (Puskurbuk) website and the textbooks published by local publishers accepted and supervised by the MoEC.

\section{Cultural representations in EFL textbooks}

Language researchers have pointed out the elaboration of which cultural elements are represented in the EFL textbooks. Cortazzi and Jin (1999) argue that there are three significant elements of cultural representation in the EFL materials, including (1) the source culture which represents the culture of learners; (2) the target culture which portray the culture where the language learned is utilized as the 


\section{Yogi Saputra Mahmud}

The respresentation of local culture in Indonesian EFL texbooks: Rationales and implications

L1; and (3) the international cultures which cover the cultures that do not belong to the source nor the target cultures. Furthermore, these international target cultures can represent either Anglophonic or nonAnglophonic countries (Messekher, 2014).

Even though there are different classifications of the cultural representations in the EFL materials, it is argued that there is always a constant issue regarding the representation of culture in these textbooks. The everlasting contention in the EFL materials deals with the cultural elements of a language is often underrepresented because they only represent a few cultural elements for one language (Kramsch, 1993). Messekher (2014) further explicates that textbooks often have "a simplistic approach to the representation of a culture" (p.70). In other words, it can indicate that the cultural representation is often reduced in terms of the quantity as well as quality in the textbooks.

As widely known that language learning in the target-removed context, such as Indonesia, is never neutral. The EFL context is continuously constructed and shaped by provincial and national policies, including the curriculum documents (Graves, 2008). In this case, this will also impact on the decision of which cultural elements should be represented and taught for the students. Consequently, this phenomenon has attracted many researchers to identify cultural elements represented in the EFL textbooks, including in the Indonesian EFL context.

Numerous studies have attempted to identify the cultural representation in the Indonesian EFL textbooks for Junior High School students. Most of the studies identify the cultural elements by categorizing these elements into three categories as proposed by Cortazzi and Jin (1999), including source culture, target culture, and international culture. In relation to the sample, the researchers analyzed the textbooks endorsed by either the government or private companies that are licensed by the government to publish English textbooks.
Table 1 below informs the findings reported by several studies in analyzing cultural representation in EFL Junior High School textbooks in Indonesia.

Table 1. Studies on cultural representation in EFL Junior High School textbooks in Indonesia

\begin{tabular}{|c|c|c|c|c|}
\hline \multirow[t]{2}{*}{ Studies } & \multirow[t]{2}{*}{ Sample } & \multicolumn{3}{|c|}{ Findings (\%) } \\
\hline & & SC & TC & IC \\
\hline \multirow{3}{*}{$\begin{array}{l}\text { Santosa } \\
(2015)\end{array}$} & When English & 73. & 8.1 & 18.18 \\
\hline & Rings a Bell & 63 & $7 \%$ & $\%$ \\
\hline & $($ Grade 7$)$ & $\%$ & & \\
\hline \multirow{7}{*}{$\begin{array}{l}\text { Erlina } \\
\text { et al. } \\
(2018)\end{array}$} & When English & 6.4 & 8.4 & $\mathrm{n} / \mathrm{a}$ \\
\hline & $\begin{array}{l}\text { Rings a Bell } \\
\text { (Grade 8) - } \\
\text { Paragraphs } \\
\text { analysis }\end{array}$ & $\%$ & $\%$ & \\
\hline & Picture & 43 & 10. & $\mathrm{n} / \mathrm{a}$ \\
\hline & analysis & $\%$ & $1 \%$ & \\
\hline & When English & 16. & 4.5 & $\mathrm{n} / \mathrm{a}$ \\
\hline & $\begin{array}{l}\text { Rings a Bell } \\
\text { (Grade 9) - } \\
\text { Paragraph } \\
\text { analysis }\end{array}$ & $9 \%$ & $\%$ & \\
\hline & $\begin{array}{l}\text { Picture } \\
\text { analysis }\end{array}$ & $\begin{array}{l}88 . \\
7 \%\end{array}$ & $\begin{array}{c}3.2 \\
\%\end{array}$ & $\mathrm{n} / \mathrm{a}$ \\
\hline \multirow{4}{*}{$\begin{array}{l}\text { Silvia } \\
(2016)\end{array}$} & English in & 40 & 18 & $2 \%$ \\
\hline & $\begin{array}{l}\text { Focus (Grade } \\
7 \text { ) }\end{array}$ & $\%$ & $\%$ & \\
\hline & English in & 23 & 53 & $11 \%$ \\
\hline & $\begin{array}{l}\text { Focus (Grade } \\
8 \text { ) }\end{array}$ & $\%$ & $\%$ & \\
\hline \multirow{2}{*}{$\begin{array}{l}\text { Mulfian } \\
\text { ti (2013) }\end{array}$} & English in & 79 & 20 & $1 \%$ \\
\hline & $\begin{array}{l}\text { Focus (Grade } \\
\text { 9) }\end{array}$ & $\%$ & $\%$ & \\
\hline
\end{tabular}

Based on the research results reported in Table 1, it is implied that source/local culture, which represents the students' culture, (see Cortazzi \& Jin, 1999) dominates the proportion of cultural elements in the textbook compared to target culture and international culture. Among the six learning materials being analyzed, there are only two textbooks that are dominated by target culture in terms of the cultural representation in the textbooks (e.g. 'When English Rings a Bell' for Grade 8; 'English in Focus' for Grade 8). By reviewing the related policy in the previous section as well as some research findings reported in this section, it can be argued that there is a strong tendency to represent the source/local 
culture more in the EFL textbooks for Junior High School students in Indonesia. Therefore, the paper attempts to discuss two arguments regarding the representation of source/local culture in the EFL textbooks that will be presented in the next section.

\section{Representing the local culture: Rationales}

There are two arguments that will be presented regarding the integration of the students' cultural identity in the EFL materials for Junior High School students. The first argument deals with the way to promote familiarity for the students in English language learning. Meanwhile, the second argument discovers the integration of the students' cultural identity as a way to promote their national cultural identity to the global contexts. The concepts of language, cultural identity, and difference will also be discussed further throughout these two arguments.

\section{Promoting 'the sense of familiarity' in learning English}

As stated in the initial part of this paper, English is formally regarded as a compulsory subject in Junior High School. Although English can be found in many public primary schools in Indonesia, this subject is not classified as a mandatory subject in that level of schooling. Consequently, it can be stated that many Indonesian students start learning English intensively in Junior High School. In addition, since there are disparities regarding the linguistic and cultural contexts between Bahasa Indonesia and English, the students will be embraced with different meanings when they learn English. Therefore, the students may find difficulties in acquiring language proficiency.

In relation to the issue above, culture as a shared meaning is produced through the system of representation which involves two different concepts, including mental representation and language (Hall, 1997). In a broader sense, further, language comprises of numerous signifying systems, such as words, images, sounds, and so on. Besides, these representational systems are agreed by the so-called social conventions where

\section{https://journal.uniku.ac.id/index.php/IEFLJ/index}

people consider certain ways of signifying the concepts they have in mind (Hall, 1997). Furthermore, this is what constructs someone as a member of a particular cultural group as language can also express and embody the cultural realities of the speech groups (see Kramsch, 1998).

Based on the discussion above, the different representation between Bahasa Indonesia and English can be one of the problems that Indonesian students might encounter. In terms of language learning, for instance, the concept of things can be represented and encoded differently by Indonesian students when they learn English since they may have different mental representation and how to signify such concepts by utilizing specific linguistic codes. For instance, there are some differences in terms of addressing people's names, greeting and leave-taking as well as cultural discourses between Bahasa Indonesia and English. Furthermore, the students' difficulties can also stem from the fact that English is not widely used outside the classroom context (see Graves, 2008). Consequently, it is argued that the incorporation of the students' cultural identity aims to make English acquisition more accessible and more accommodating for Junior High School students who are still in the initial phase of language acquisition.

Language researchers also discuss the importance of incorporating students' cultural identity in EFL materials. It is argued that integrating the reading materials that are replete with the cultural symbols shared by both the students and teachers can reduce the feeling of alienation since the learners are familiar with the topic being learned (Nault, 2006; Neba, 2016). Furthermore, it is also suggested that learning English through the use of such materials will not only make the learning acquisition more accommodating for the students but also preserve the students' cultural identity. Moreover, the students will be easier to discuss their cultural realities through English toward people from other cultural backgrounds (Nault, 2006). In relation to the 
The respresentation of local culture in Indonesian EFL texbooks: Rationales and implications

students' level, Barrios and de Debat (2014) argue that incorporating the students' cultural identity when their L2 competence is still considered limited could facilitate the learner's autonomy since the learning materials are familiar with their existing knowledge. Consequently, this implies the importance of incorporating the students' cultural identity in the EFL textbooks for Junior High School students.

To illustrate the use of local culture in the EFL discourse, an excerpt from a textbook published by the MoEC in Indonesia for Grade 9 of Junior High School is presented below.
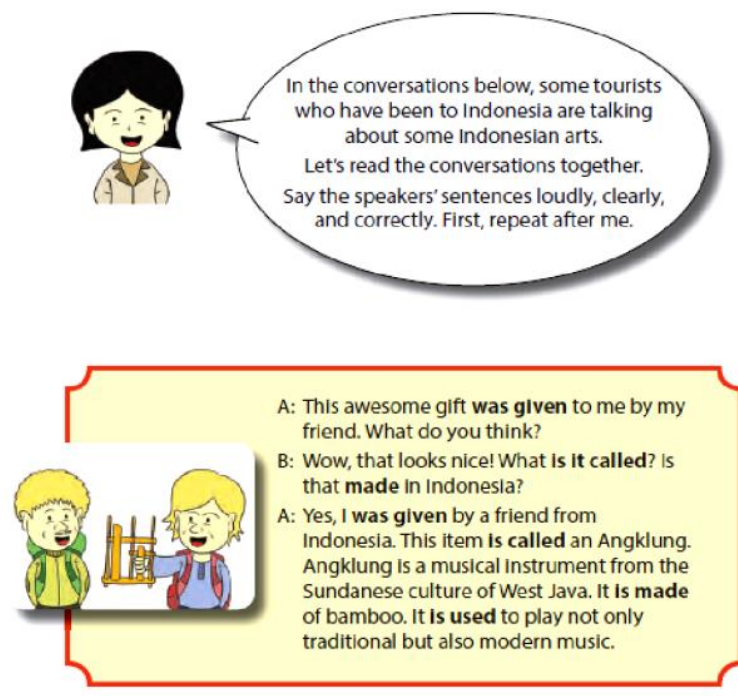

Figure 1. An excerpt from the book "Think Globally Act Locally" for Grade 9 (see Wachidah, Diyantari, \& Khatimah, 2015)

This excerpt is taken from a book published by the government for Grade 9 of Junior High School published by The Center of Curriculum and Materials (Puskurbuk) for the implementation of the 2013 Curriculum in Indonesia. In this chapter of the book, the students are expected to learn how to describe things surrounding their environment. In this case, the students are encouraged to learn how to describe things through the portrayal of a traditional musical instrument called 'Angklung'. In addition, it can be identified that this excerpt attempts to integrate the local cultural components through 'Angklung' in order to help the students understand the concept of describing things.

The phenomenon above is also discovered by Nomnian (2013) when the researcher analyzed the textbooks published for secondary school students in Thailand. The researcher suggests that Thai students will be more accessible to refer the concept of a three-wheeled vehicle by signifying it as tuk-tuk since the students have possessed to 'imagine' their existing mental representation and 'emerge' and 'translate' it into English. As a consequence, this will eventually create shared meanings between the students and they will be easier to describe things familiar with their daily contexts. Similarly, the excerpt from a textbook endorsed by the government for Junior High School students also utilize the traditional musical instruments to make the learning materials more accommodating for the students because they are already familiar with the content of the discussion. Therefore, engaging the students' cultural experiences will lead to better comprehensibility to utilize language by the students.

The integration of local culture in EFL learning materials, however, is not unproblematic. Since Indonesia is comprised of various ethnic groups, there are even cultural disparities within their society. This statement is also highlighted by Nomnian (2013) who suggests that not all students in Thailand might comprehend specific topics in the EFL materials as there are several different cultural concepts and practices. For instance, the researcher clarifies that "tuktuk" is only used in the metropolitan area of Bangkok (Nomnian, 2013). Similarly, the use of Angklung in Picture 1 should also be balanced with the other cultural experiences of the students because some students might not understand the concept of Angklung, which is from West Java, to be described by using English.

Besides promoting familiarity for the Junior High School students as the beginner learners of English, the inclusion of students' cultural identity in the Indonesian 
EFL materials is also understood as a strong indication regarding the shift of focus in learning English to promote the national identity of the students through the EFL learning materials. This phenomenon occurs due to the needs to share the cultural identities in the nation to global communities through the utilization of English (Gunantar, 2017) that will be discussed further in the next section.

\section{Reinforcing national identity}

As stated in the initial part of this article, English is regarded as a compulsory subject since Junior High School level. Furthermore, as a country in the TL-removed contexts (see Graves, 2008), English is not primarily used in society outside the classroom context. Consequently, unlike the TL-embedded contexts which have target needs present within the society, e.g. Malaysia, Singapore, Nigeria, the TL-removed contexts should create or even imagine a particular context in which English should be used. In the countries where English is not mainly communicated within their society, the English learning context is actively shaped, adapted, and changed in order to accommodate the distinct needs of each nation (Nault, 2006). In this case, the curriculum policies in Indonesia shape the decision to integrate the students' cultural identity within the EFL materials as they need to contextualize the English learning for the students.

The purpose of learning English in the Junior High School level is to enable the students to express about themselves, family, as well as other activities that they conduct within their daily context (see MoEC, 2016a). Based on the statement in the government syllabus of English for Junior High School, the teachers are also encouraged to adapt the learning materials based on the cultural and geographical characteristics of the students (see MoEC, 2016c). Consequently, the incorporation of the students' cultural identity in the EFL material can indicate that there is a strong desire from the governments to equip the students with the knowledge of the students'
p-ISSN 2252-7427, e-ISSN 2541-3635

https://journal.uniku.ac.id/index.php/IEFLJ/index

cultural identity while learning English. In other words, English is now perceived as an access for the students to bring and introduce the students' cultural resources and national identity to the global community (see Gunantar, 2017).

Based on the constructionist view, the notion of national cultural identity refers to the collective identities formed by the national cultures as one of the primary sources of identity through the production and exchange of meaning as a so-called nation to identify one with others (Hall, 1996, as cited in Tsui \& Tollefson, 2007). According to Hall (1997), people belong to the same culture when they share a similar way to encode and interpret signs from a language. Consequently, the use of local cultural values is perceived to signify that the students are Indonesians. In relation to the use of the students' cultural values in the English textbooks, the government would like to enable the students to compete in the international level and eventually belong to 'the international community' without neglecting their own national identity.

In addition, Tsui and Tollefson (2007) argue that the identification of national cultural identity proposed by Hall (1996, as cited in Tsui \& Tollefson, 2007) is closely related to the notion of imagined communities. Furthermore, they also explicate the discussion of national cultural identity through the four elements. First of all, the notion of national identity can have a close relation to the national spirit to express the unprecedented features of a nation and national culture (Tsui \& Tollefson, 2007). Second, the national identity can be invigorated by the shared historical memory of a nation, whether it is real, partly real or even imaginary (Tsui \& Tollefson, 2007). Third, the future orientation of a nation can also emphasize the incorporation of national identity within learning contexts which strictly deals with global competitiveness (Tsui \& Tollefson, 2007). Fourth, the emphasis on the origin, tradition, and the cultural realities of a nation (Tsui \& Tollefson, 2007). From the analysis of the 
national identity promotion through these concepts, the inextricable relationship between these concepts and the EFL materials for Junior High School in Indonesia will be explored further in the next paragraphs.

The first and fourth concepts of national identity proposed by Tsui and Tollefson (2007) can indicate a significant role of difference in constructing identities. In relation to that, identity is also considered relational since identity can only be constructed through the difference between one and another (Hall, 1997; Woodward, 1997). Thus, we should be able to know other identities in order to understand our distinct features as a nation or national culture. In the context of EFL materials in Indonesia, the textbook materials are primarily driven by the enactment of curriculum policies. In this case, the national education, including the EFL in Indonesia should be based on the values of Pancasila as the uniting principles for the Indonesian students. Through the cultural contents of the EFL materials, students are further expected to promote the sense of belonging as well as to show their unique features to the international community (Gunantar, 2017).

The second concept of national identity proposed by Tsui and Tollefson (2007) is represented through the incorporation of the historical stories of a nation, whether it is real, partly real or even imaginary. In this case, these concepts are represented in the EFL textbooks for the Indonesian Junior High School students through local folktales when the students learn about narrative texts, for example in Grade 9 (see MoEC, 2016c). In response to the fact that local cultures are integrated into the textbooks, Kirkpatrick (2007) argues that it can reflect the necessities of Indonesians to talk about the values due to social, political, and cultural changes that are experienced by the Indonesians. He further explicates that providing opportunities for Indonesian students to acquire their cultural values will equip the students to talk about their cultural identity to other communities in English (Kirkpatrick, 2007).

In conclusion, integrating the students' cultural identity can be perceived as a way to promote familiarity for the students as well as to make the learning more accommodating. Since English is only regarded as a compulsory subject at Junior High School, many students are assumed to find the learning process difficult to follow if they are not familiar with the learning contents. In addition, the incorporation of the students' cultural identity is also seen to promote the national cultural identity to the international community by using English. Ultimately, the discussion above leads to further considerations that should be concerned by related parties, such as teachers as the user of the textbooks as well as the policymakers to consider the future direction of the Indonesian EFL curriculum.

Future implications for Indonesian EFL context

Although the integration of local culture has been justified, it is not unproblematic since there are several implications that different parties should consider. In this paper, two predominant implications should be concerned in responding to the incorporation of local culture in EFL textbooks for Junior High School students in Indonesia.

\section{Teachers role}

It has been widely acknowledged that teachers, as the textbook users, have an essential role in culture-based teaching in the EFL context. Messekher (2014) suggests that "no matter what cultural representations are used in textbooks; their effectiveness depends on how they are taught" (p. 83). In other words, teachers contribute significantly to the success of EFL teaching no matter which cultural elements are represented in the EFL textbooks. Furthermore, teachers should also understand the overall purposes of teaching culture as well as the cultural aspects represented in the textbooks. When teachers possess the ability to comprehend the reasons why the cultural elements are represented that way in the textbook, they will help develop the students' cross-cultural 
understanding which eventually leads to the students' cultural awareness and acknowledgment of the cultural diversity (Messekher, 2014).

Although the importance of teachers' role in the culture-based EFL teaching has been widely acknowledged, the Indonesian EFL context has its own complexities. Kirkpatrick (2007) argues that insufficient numbers of trained English teachers are one of the major problems in the Indonesian EFL context. Therefore, there is a strong indication that teacher training is essential in order to achieve effective English teaching with the integration of students' cultural identity within the learning materials. By conducting training for English teachers, it is expected that the integration of students' cultural identity will be more effective. In relation to the skills that English teachers should possess, Kirkpatrick (2007) has elaborated several points that teachers should have in the multicultural EFL paradigm.

First, teachers should understand the social and cultural contexts of the school environment as well as acknowledge the language of their students (Kirpatrick, 2007). In other words, teachers should recognize that the students' social and cultural identities are the excellent resources to acquire a new language, i.e. English. Second, teachers should also understand that different varieties of English have developed in various ways, including in phonological, linguistic, grammatical, and cultural ways (Kirpatrick, 2007). Therefore, teachers should not regard the students to talk about their cultural identities in English as inferior as those who talk about what so-called target cultural norms. Third, it is also essential for the teachers to critically evaluate the textbooks utilized in the EFL context and to adapt the materials with the specific needs of their students, with the equal proportion of cultural representations without neglecting each cultural element in the community (Kirkpatrick, 2007).

Consequently, the integration of the students' cultural identity in the EFL
p-ISSN 2252-7427, e-ISSN 2541-3635

https://journal.uniku.ac.id/index.php/IEFLJ/index

textbooks requires the trained plurilingual teachers who can critically evaluate the cultural elements represented in the materials by considering the students' specific needs, the equal proportion of the cultural representations as well as the sensitivity of cultural diversities in Indonesia. Furthermore, the incorporation of cultural elements in the EFL textbooks should also consider the future direction of the EFL curriculum implemented in Indonesia which will be elaborated further in the next section.

\section{Moving beyond the local culture}

Besides the role of teachers as the textbook users and the cultural agents in the classroom, the future direction of the Indonesian EFL curriculum should also be considered. As discussed above, the 2013 curriculum dramatically emphasizes to include the students' cultural values within the curriculum, including the prescribed learning materials. However, since it is widely known that Indonesia has diverse cultural varieties, the students' cultural values in the specific geographical area might not be presented. Consequently, the curriculum should specifically point out the flexibility of the teachers to appropriate the learning materials in order to transmit relevant cultural values for the students in the specific area. In other words, the curriculum policies, starting from the content standard to the prescribed EFL textbooks for Junior High School should also consider the cultural diversity.

The complexity of EFL context in Indonesia is also increased by the fact that the globalization and the community integration of the ASEAN (Associated of the Southeast Asian Nations) countries have been established within the ASEAN Economic Community (AEC) since 2015. Throughout this period, English has been utilized as a lingua franca, or the communication between the ASEAN people themselves (Kirkpatrick, 2007). Consequently, the economic and cultural partnership between the nations will also have impacts on English education within 
the countries. For instance, Tantiniranat (2015) has indicated the needs to not only reinforce the students' cultural identity of their nation, but also acknowledge the sense of belonging and citizenship in the wider community, including ASEAN and the global community. In other words, the EFL curriculum in Indonesia should also address these issues in order to enhance the cooperation and partnership by accommodating both the students' cultural identity as well as the cultural values of the other ASEAN nations to promote crosscultural awareness and understanding.

However, this issue is also considered very complex since ASEAN is also comprised of different nations with very diverse cultural identities. This is also acknowledged by Kirkpatrick (2008) who argues that English in ASEAN consists of multiple varieties. In other words, the English learners in Indonesia might expect to meet a wide range of English varieties when they communicate with the ASEAN members. Therefore, the students might get confused when they are not introduced with these kinds of variations in the curriculum, including in the learning materials. As the biggest country in terms of population and geographical area, Indonesia will receive a significant increase of the tourism and investment influx from the other ASEAN countries. Consequently, the needs to rebalance the representations of cultural identities between the students' nation and other nations should be taken into considerations.

\section{CONCLUSION}

In summary, several concepts have been presented and elaborated in this paper. First, the context of the EFL curriculum in Indonesia has been explained thoroughly from the elaboration of the National Education System in Indonesia. Furthermore, the 2013 curriculum as the latest curriculum implemented in Indonesia, the Content Standard, the syllabus for Junior High School students, until relevant policies regarding the use of textbook materials in the Indonesian EFL context has also been discussed. Second, the cultural representations in the EFL materials have also been addressed through the analysis of language researchers. Third, two arguments have also been justified regarding the incorporation of the students' cultural identity in the EFL textbooks for Junior High School students. Fourth, the implications to enhance the role of teachers in the Indonesian EFL context, as well as the needs to consider the future direction of the Indonesian EFL curriculum by extending the focus of incorporating culture in the textbooks have also been discussed.

Thus, in relation to the future research agenda, there are three dimensions of research that can be explored further by future researchers who are interested in this topic. First, researchers are encouraged to investigate the categories of culture beyond the notion of the source, target, and international culture. In this case, future researchers can focus on the types of cultural elements, including practices, beliefs, aesthetic aspects, and many more. Second, the study on analyzing cultural elements in EFL textbooks should also aim to examine teachers' attitudes and strategies in dealing with the cultural elements represented in EFL textbooks. Third, it is also recommended that researchers discover the students' beliefs and preferences regarding the cultural values in the textbooks as well as the impact of cultural elements on their learning motivation.

\section{REFERENCES}

Barrios, M. L., \& de Debat, E. V. (2014). Global vs Local: Does it matter? In S. Garton \& K. Graves, International perspectives on materials in EFL. New York: Palgrave Macmillan.

Choudhury, M. H. (2013). Teaching culture in EFL: Implications, challenges and strategies. IOSR Journal of Humanities and Social Science, 13(1), 20-24.

Cortazzi, M., \& Jin, L. (1999). Cultural mirrors: Materials and methods in the EFL classroom. In Hinkel, E. (ed.), Culture in second language teaching and learning (pp. 196-219). Cambridge: Cambridge University Press.

Erlina, D., Marzulina, L., Pitaloka, N. L., Astrid, A., Yansyah, F., \& Mukminin, A. (2018). Research 
on educational media: Balancing between local and target language cultures in English electronic textbooks. TOJET: The Turkish Online Journal of Educational Technology, 17(2), 111-119.

Fiedler, S. (2011). English as a lingua franca: A native-culture-free code? Language of communication vs. language of identification. Apples - Journal of Applied Language Studies, 5(3), 79-97.

Graves, K. (2008). The language curriculum: A social contextual perspective. Language Teaching, 41(2), 147-181.

Gunantar, D. A. (2017). Textbook analysis: Analyzing English as a foreign language (EFL) textbooks from the perspective of Indonesian culture. Journal of Language and Literature, 11(2), 173-182.

Hall, S. (ed.) (1997). Representation: Cultural representations and signifying practices. London: Sage Publications.

Hall, S. (2013). The work of representation. In S. Hall, J. Evans \& S. Nixon (Eds). Representation $\left(2^{\text {nd }}\right.$ Ed) (pp. 1-47). London: Sage Publications.

Hawanti, S. (2014). Implementing Indonesia's English language teaching policy in primary schools: The role of teachers' knowledge and beliefs. International Journal of Pedagogies \& Learning, 9(2), 162-170.

Hermawan, B., \& Noerkhasanah, L. (2012). Traces of cultures in English textbooks for primary education. Indonesian Journal of Applied Linguistics, 1(2), 49-61.

Jayanti, F. G., \& Norahmi, M. (2014). EFL: Revisiting EFL practices in Indonesia. Journal on English as a Foreign Language, 4(1), 5-14.

Kachru, B. B., Kachru, Y., \& Sridhar, S. N. (2008). Language in South Asia. Cambridge: Cambridge University Press.

Kirkpatrick, A. (2007). Teaching English across cultures: What do English language teachers need to know how to teach English? English Australia Journal, 23(2), 20-36.

Kramsch, C. (1993). Context and culture in language teaching. Oxford: Oxford University Press.

Kramsch, C. J. (1998). Language and culture. Oxford, OX: Oxford University Press.

Law on the National Education System 2003 (IDN). Available from http://www.ilo.org.

Messekher, H. (2014). Cultural representations in Algerian English textbooks. In S. Garton \& K. Graves. International Perspectives on Materials in EFL. New York: Palgrave Macmillan.

Ministry of Education and Culture. (2016). Lampiran Peraturan Menteri Pendidikan dan Kebudayaan Nomor 21 Tahun 2016 tentang Standar Isi Pendidikan Dasar dan Menengah. Jakarta. Retrieved from http://bsnp-indonesia.org/.

Mulfianti, I. A. (2013). The cultural content on English textbook used by Junior High School
https://journal.uniku.ac.id/index.php/IEFLJ/index

students. (Undergraduate Thesis, Satya Wacana Christian University, Salatiga, Indonesia). Retrieved from http://repository.uksw.edu/

Munandar, M. I., \& Ulwiyah, I. (2012). Intercultural approaches to the cultural content of Indonesia's high school EFL textbooks. CS Canada: CrossCultural Communication, 8(5), 67-73.

Nault, D. (2008). Going global: Rethinking culture teaching in EFL contexts. Language, Culture and Curriculum, 19(3), 314-328.

Neba, D. C. (2016). Culture and identity: Towards redefining representational material for the ESL/EFL classroom. Asian Journal of Social Sciences \& Humanities, 5(2), 172-179.

Nomnian, S. (2013). Thai cultural aspects in English language textbooks in a Thai secondary school. Veridian E-Journal, 6(7), 13-30.

Prastiwi, Y. (2013). Transmitting local cultural knowledge through English as Foreign Language (EFL) learning as a means of fostering "Unity in Diversity". Academic Journal of Interdisciplinary Studies, 2(3), 507513

Prihantoro, C. R. (2015). The perspective of curriculum in Indonesia on environmental education. International Journal of Research Studies in Education, 4(1), 77-83.

Purba, H. (2011). The importance of including culture in EFL teaching. Journal of English Teaching, 1(1), 44-56.

Puspitasari, S. N. (2016, March 21). Tahun ini, kurikulum 2013 diterapkan secara nasional [This year, Kurikulum 2013 is implemented in national scale]. Pikiran Rakyat. Retrieved from http://www.pikiran-rakyat.com.

Santosa, I. (2015). Cultural representation in English textbook for junior high school. Eduscience Journal (ESJ), 1(1), 25-32.

Silvia, A. (2014). Cultural content in English textbooks used at Madrasah Tsanawiyah Negeri in DKI Jakarta. (Master's thesis, UIN Syarif Hidayatullah, Jakarta, Indonesia). Retrieved from http://repository.uinjkt.ac.id.

Sukyadi, D. (2015). The teaching of English at secondary schools in Indonesia. In B. Spolsky \& K. Sung (Eds.). Secondary schools English education in Asia: From policy to practice. Abingdon, Oxon: Routledge.

Sorongan, D. A., Susanti, R., \& Syahri, I. (2014). An analysis of local and target culture integration in English textbooks. LINGUA, Jurnal Bahasa \& Sastra, 15(1).

Tantiniranat, S. (2015). Some intercultural implications of ASEAN and Thai educational policies for Thai higher education. CORERK: Cambridge Open-Review Educational Research e-Journal, 1(2), 154-165.

Tsui, A. B. M., \& Tollefson, J. W. (Eds.). (2007). Language policy, culture, and identity in Asian 


\section{Yogi Saputra Mahmud}

The respresentation of local culture in Indonesian EFL texbooks: Rationales and implications

contexts. Mahwah, NJ, US: Lawrence Erlbaum Associates Publishers.

Wachidah, S., Diyantari, D., \& Khatimah, Y. R. (2015). Think globally act locally. Jakarta: Ministry of Education and Culture.

Widodo, H. P. (2018). A critical micro-semiotic analysis of values depicted in the Indonesian ministry of national education-endorsed secondary school English textbook. In H. P. Widodo, M. R. Perfecto, L. V. Canh, \& A. Buripakdi. (Eds.), Situating moral and cultural values in EFL materials: The Southeast Asian context. Switzerland: Springer.
Woodward, K. (1997). Identity and difference. London: Sage in association with the Open University.

Yusny, R. (2013). EFL in Indonesian context: Issues and challenges. Englisia, 1(1), 81-99. 